\title{
初中政治教学中时事政治的应用与作用
}

\author{
雷玉亮 \\ 广西省河池市宜州区屏南中学 \\ DOI:10.32629/jief.v2i10.2255
}

[摘 要] 在信息技术不断进步发展的时代背景下, 要想提升教学效率, 除了要优化教学方式外, 也要紧跟信息发展步伐, 结合信息时效性优 化政治教学工作水平，从而维护教学质量和教学效果。本文分析了初中政治教学中时事政治的作用，并对相应的教学应用方式展开讨论。 [关键词] 初中政治; 时事政治; 作用; 应用

中图分类号: G633 文献标识码: A

时事热点是重要的政治教学资源, 教师需要结合时事政治信息开展 对应的教学设计, 从而打造高效课堂, 提高学生对时事热点的认知水平, 为教学质量的全面进步提供保障。

\section{1 初中政治教学中时事政治的作用}

对于初中政治教学工作而言, 教师要利用多元化信息收集渠道完成 信息的汇总, 借助时事政治新闻提高学生的学习兴趣, 激发学生的学习 积极性是最关键的。教师在合理性应用热点新闻的过程中, 应引导学生 在信息检索和了解的过程中学会主动学习, 并且为学生提高政治核心素 养奠定基础。

另外, 时事新闻热点内容也是政治理论研究的新方向和重点, 因此, 学生在学习的过程中能提高对政治学习内容的学习体验。基于此, 充分 发挥时事政治新闻教育内容的作用, 确保能落实针对性总结和引导机制, 就能提高学生的政治敏感性, 为后续学习提供良好的指导, 并且为学生 树立正确的核心价值观和健康成长提供保障。所以, 初中政治教学中渗 透时事政治内容具有重要的实践教育意义。

\section{2 初中政治教学中时事政治的应用}

在明确初中政治教学中时事政治教学工作的作用后, 就要结合学生 的基本学情落实相应的教学工作, 确保教学环节和教学内容有效衔接, 灵活的引入时事政治内容, 在突出学生学习主体性的基础上, 应用专题 教学的模式提高学生的学习积极性, 从而培养初中学生的政治素养。

2.1 善用主体性教学

相较于传统的教学模式, 素质教育推崇突出学生的主体性地位, 教 师要作为辅助角色适当落实教学引导, 有效保证学生在学习资料收集、 接纳的过程中形成自己的认知, 并且发表意见和观点, 提升学生的学习 独立性, 也为学生质疑精神和创新精神的培养奠定基础。因此, 在初中 政治教学中应用时事政治新闻内容, 就要打造以学生为主体的教学框架, 激发学生的主观能动性, 为学生综合素质的进步提供保障。

一方面, 因为时事政治新闻内容较多, 尤其是信息网络不断发展的 当下, 各类新闻内容层出不穷, 这就需要教师引导学生从众多信息中提 取有效信息、关键信息。教师要借助个性化设计模式保证学生表达空间 符合教学需求, 并且创设轻松愉快的教学氛围。教师可以引导学生收集 相应的时事热点新闻, 基于学生的选择和内容教师开展对应的教学设计, 鼓励学生针对自己选取的新闻发表相应的看法和见解。最重要的是, 要 结合课堂教学内容的逻辑不断丰富相应信息, 从而确保教学效果符合预 期教学目标。

另一方面, 教师在学生发表相应见解的过程中可以适当进行引导, 确保学生能学习到高质量的政治教学内容, 优化学生的学习实力和综合 素养。教师可以采取分组教学的模式, 针对同一个教学内容引导不同小 组探讨并发表见解, 并且引导学生应用课本中的政治知识内容和专业化 政治学术用语解释时事新闻。

\section{2 善用主题教学}

对于初中政治教学工作而言, 主题型教学模式是较为有效的教学方 式, 在主题教学的过程中应引导学生收集相应的时事新闻热点, 全面丰 富知识内涵, 打造更加合理且高效的教学模式。相较于传统理论性讲授 政治内容的方式, 教师应将时事政治新闻融合到教学中, 有效提升学生 的政治学习兴趣和热情, 确保能在引导学生自主性学习的过程中形成社 会主义核心价值观。需要注意的是, 因为时事新闻热点具有动态性特点,
因此，教师可以对具有共同点的时事新闻热点予以汇总处理，提高教育 教学的综合价值。

第一，阶段性主题教学。教师可以结合课程内容与当下最热门的时 事政治信息进行阶段性主题处理, 例如, 2022 年冬奥会、上合组织峰会 等, 要求学生搜集相应的信息, 并且利用专题讲解的模式强化政治教学 的综合效果，为整体政治教育工作的全面优化奠定基础。

第二, 战略性主题教学。教师在实际教学工作开展的过程中, 不能 一味盲目的引入时事政治新闻而忽略主体教育内容, 而是要结合基础理 论教学框架融入时事新闻热点, 提高学生的政治实践能力, 也为学生综 合政治学习素养的进步提供保障。也就是说, 教师在开展时事政治教学 内容的过程中, 要拓展学生的政治学习时域, 保证学生能具有战略性的 政治学习素养, 提高学生信息提炼的能力。例如, 教师在讲解一带一路 的相关内容时, 就可以引导学生收集相应的信息, 并且对我国这几年一 带一路的成果和展望进行总结, 优化学生对知识内容的认知高度, 培养 学生的政治敏感度。

第三，精炼性主题教学。时事政治新闻较多，如何有效进行信息的 提取是教学的关键, 因此, 教师在主题性教学工作开展的过程中都要引 导学生提炼信息精华, 培养学生知识总结和归纳的能力, 确保能借助专 题性的热点教育引导工作优化学生政治学习的综合效果和学生的整体素 养。

\section{3 善用实践活动}

为了进一步凸显时事政治新闻的教学价值, 教师除了在课堂中建立 主题性教学外, 也要利用实践活动提高学生对于新闻的认知力, 更好地 内化相应的教学内容。在开展时事新闻热点主题活动的过程中, 教师要 秉持教育方案长效性的原则, 利用政治时事新闻热点学习活动周等方式 调动学生的学习积极性, 从而结合初中政治教学内容开展相应的教学工 作, 为学生政治学习素养的提高提供保障。

除此之外, 教师也要亲力亲为地进行实践指导, 为学生树立模范, 确保学生能积极的参与到活动中, 优化学习氛围的基础上保证学生政治 实践学习效果符合综合人才培养目标。

\section{3 结束语}

总而言之，教师要借助时事政治新闻活跃初中政治课堂的氛围，打 造更加和谐、高效、互动性的课堂模式, 提高学生政治课程学习的积极 性和课堂质量, 培养学生的政治信息检索能力和政治敏感性, 为学生综 合素质的全面优化奠定坚实基础, 也能促进学生身心健康发展。

\section{[参考文献]}

[1]庄丽球.浅谈如何在初中道德与法治课堂教学中灵活引入时事政 治[J].情感读本,2020(15):20,22.

[2]常亚斌.浅谈初中政治教学中如何运用好时事热点 [J]. 才 智, 2020(9):70.

[3]李红年. 时事政治在初中政治课堂教学中的应用 [J].中学课程辅 导 (教学研究) ,2020,14(2):174-175.

[4]张海维.引入时事资源,发展初中生政治认同素养[J].新课程导 学, 2020(5):24.

[5]叶青.初中政治教学中如何运用好时事热点[J].教书育人 (教师新 概念 ) ,2020(3):16. 